$\begin{gathered}\text { ADVANCE RESEARCH JOURNAL OF SOCIAL SCIENCE } \\ \text { Rolume } 9 \mid \text { Issue } 2 \mid \text { December, 2018 | 254-257 } \\ \text { REIIEW }\end{gathered}$
DOI: 10.15740/HAS/ARJSS/9.2/254-257

\title{
Kollam Port : An emporium of Chinese trade
}

\author{
H. Adabiya
}

Department of History, Iqbal College, Peringammala, Thiruvananthapuram (Kerala) India

Email: adabiyaiqbal@gmail.com

\section{ARTICLE INFO :}

Received : $\quad 21.10 .2018$

Accepted : 26.11.2018

\section{KEY WORDS :}

Maritime relations, Emporium, Chinese trade, Commercial hub

HOW TO CITE THIS ARTICLE : Adabiya, H. (2018). Kollam port : An emporium of Chinese trade. Adv. Res. J. Soc. Sci., 9 (2) : 254-257, DOI: 10.15740 /HAS/ARJSS/9.2/254-257. Copyright @ 2018 : Hind Agri -Horticultural Society

\begin{abstract}
Kerala had maintained active trade relations across the sea with many countries of the Eastern and Western world. Kollam or Quilon was a major trading centre on the coast of Kerala from the remote past and has a long drawing attraction worldwide. The present paper seeks to analyze the role and importance of Kollam port in the trade relation with China. It is an old sea port town on the Arabian coast had a sustained commercial reputation from the days of Phoenicians and the Romans. It is believed that Chinese were the first foreign power who maintains direct trade relation with Kollam. It was the first port where the Chinese ships could come through the Eastern Sea. Kollam had benefitted largely from the Chinese trade, the chief articles of export from Kollam were Brazil wood or sapang, spices, coconut and areca nut. All these goods had great demand in China and the Chinese brought to Kerala coast goods like silk, porcelain, copper, quick silver, tin, lead etc. Chinese net and ceramics of China had great demand in Kerala coasts and Kollam was an important centre of Chinese goods. Recently the port trust had discovered thousands of Chinese coins and stone age weapons from the Kollam Port, which is revealing the amazing historic background and trade culture of the port city. This is first time that these much of artifacts are getting from a port in India. The emergence of antiques from Kollam Port area reveals that Kollam was the most famous port city in India which served as the business hub of Chinese trade. It is an established fact that Kollam was a repository of all sorts of conceivable commercial centre.
\end{abstract}

